estimated that the 2,000 new cases seen annually represents the sifting of cases from a population of approximately 6,000,000. The proportion of cases sent in for treatment from each district tends to vary inversely with the distance from the

TABLE 4.

\begin{tabular}{|c|c|c|c|c|}
\hline Year & $\begin{array}{c}\text { No. of patients } \\
\text { referred from } \\
\text { civic area** } \\
\text { (Population } \\
1,039,740 .)\end{array}$ & $\begin{array}{c}\text { No. referred } \\
\text { per 100,000 } \\
\text { population. }\end{array}$ & $\begin{array}{c}\text { No. of patients } \\
\text { referred from } \\
\text { immediately } \\
\text { surrounding } \\
\text { areaf. (Popula. } \\
\text { tion 1,663,860.) }\end{array}$ & $\begin{array}{c}\text { No. referred } \\
\text { per 100,000 } \\
\text { population. }\end{array}$ \\
\hline 1931 & 465 & 44 & 362 & 21 \\
1932 & 434 & 41 & 365 & 21 \\
1933 & 474 & 45 & 462 & 27 \\
1934 & 496 & 47 & 736 & 44 \\
1935 & 572 & 55 & 794 & 49 \\
\hline Increase over 5 years-25 per cent & Increase over 5 years-133 \\
per cent & \\
\hline
\end{tabular}

* Civic area includes the cities of Manchester and Salford.

t Surrounding area is the south-east quarter of Lancashire (excluding Manchester civic area), bounded by the line, Cheshire border, Warrington (exclusive), Preston (inclusive), Yorkshire border.

centre. Thus in the immediate local area (Manchester, Salford and Stockport), practically all cases come for consideration regarding treatment, while in the periphery of the zone served, a smaller fraction is referred unless steps are taken to increase it. This situation is demonstrated by
Table 4, which also shows the results of the measures adopted by the Institute to reach patients in the surrounding area.

This improvement in the availability of treatment to patients has been achieved by the development in connexion with the Institute of clinics not only in Manchester in its own hospitals, but also in a large number of voluntary hospitals of towns in the area served (see accompanying map). Treatment clinics are also held, but in a more limited number of such outside hospitals. There the simpler cases are dealt with, while those more complex are brought for treatment to the central unit where the facilities are greater. In the same way the Institute has entered into agreements with City and County Health Authorities by which cases of cancer in their control are seen, and if suitable for radio-therapy are treated.

In conclusion, there are many indications that as national organization for the treatment of cancer evolves, it may be necessary to develop it along lines similar to those now accepted for the treatment of tuberculosis, that is, along modified State service lines. In this case, the unit and the organization described above may prove to have been in some respects a prototype.

\title{
Recent Developments in the Geology of the U.S.S.R.
}

\section{By Prof. N. N. Gornostayev*}

$\mathrm{T}$ HE successive Five Year Plans in the Soviet Union have been accompanied by a vigorous development of geological science, and new mineral wealth is being discovered almost daily by the 6,000 geologists who are employed in prospecting over the whole vast area of the U.S.S.R. Soviet deposits of oil, coal, peat, iron, manganese, gold, potash salts and phosphates, are among the largest in the world.

In 1913 the known coal deposits of Russia comprised but 3.2 per cent of the world's resources, as estimated by the Twelfth International Geological Congress. At the Seventeenth Congress held in Moscow last year, the estimated coal resources of the Soviet Union were found to be seven times greater than in 1913, comprising $1,654,361$ million tons, or nearly 21 per cent of the world's coal reserves.

In addition to the Donetz Basin, which yielded 87 per cent of the coal mined in Russia in 1913, large coal deposits have been discovered in Kazakhstan, Siberia and the Far East. The coal deposits of European Russia now comprise only

* Revised and abridged by Dr. G. W. Tyrrell from an article entitled "Soviet Geology" received from the Soviet Union Year Book Press Service.
$9 \cdot 1$ per cent of the total resources of the U.S.S.R. This more uniform distribution of coal resources has made widespread industrialization much more feasible.

The iron ore deposits of the Soviet Union are now known to be five and a half times greater than was estimated in 1913. The reserves of oil are fourteen times greater than was estimated in 1905. Oil fields have been found along the entire Urals range, and prospecting is in progress on the vast Siberian plains. It is possible that Siberia will be found to contain some of the richest oil deposits in the world. Incidentally, Siberian oil is the oldest known, as it is found in Cambrian formations.

It is now established that about 83 per cent of the world's known resources of potash are concentrated in the U.S.S.R., and these resources are being steadily augmented by new discoveries. More than 73 per cent of the world's manganese ore reserves are contained within the Soviet Union. The huge deposits of apatite found in the Kola Peninsula have doubled the world's resources of phosphates. 
The U.S.S.R. holds second world place in respect of gold output. The gold industry, which formerly employed the most primitive methods, has now been greatly modernized. Large nuggets are often obtained, as, for example, one of $32 \mathrm{kgm}$. which was found in the Miass (Urals) gold field.

The desolate region of Kazakhstan, the roving ground of nomadic tribes, is now the main Soviet source of supply of non-ferrous metals, especially copper, zinc and lead, and has far outstripped the Urals, the former source of these metals. Until recently the U.S.S.R. was thought to be lacking in boron, but huge deposits of boracic salts have been found in the region around Lake Inder in north-west Kazakhstan.

The geological structure of the U.S.S.R. is exceedingly varied. On its territory are huge mountain folds which have risen on the sites of former sea depressions filled with soft clays, sands and limestones (for example, the Caucasus). There are mountains which are fragments of ancient rocks split into uneven blocks which have moved upward or downward (for example, the Tian-Shan, Altai, etc.). There are deep depressions such as Lake Baikal (the largest freshwater lake in the world, more than $1520 \mathrm{~m}$. deep), and the Black and Caspian Seas, formed in geologically recent times.

The wide plains of West Siberia are now known to cover the greater part of the former range of the Urals. The Urals of to-day represent merely the western margin of this great Hercynian range and, moreover, were elevated in comparatively recent geological times.

Formerly, the Crimean mountain range was as extensive as the Caucasian, but, broken by enormous faults, it sank, and now lies beneath the floor of the Black Sea at a depth of more than $2000 \mathrm{~m}$. The Crimean mountains of to-day are merely a remnant of the northern part of the ancient range.

Some Western geologists have maintained that oceanic depressions have always existed, and that the Pacific Ocean constitutes the 'scar' caused by the parting of the moon from the earth. Recent work by Soviet geologists has shown, however, that the northern part of the Pacific, until comparatively recent times, was a vast continent with mountain chains, hills, plains and volcanoes, stretching between Siberia and North America.

The variety and complexity of geological structures in the U.S.S.R. explain the variety of igneous rocks within its territories. Practically all known varieties of igneous rocks have been found. The largest developments of nephelinerich igneous rocks in the world, with many rare and rare-earth minerals, and enormous deposits of apatite, have long been known to occur within the Kola Peninsula. Entire mountains of sodic sanidinites, hitherto known only in the form of separate lumps in voleanic ejecta, have been found in Kazakhstan.

Study of the mineral springs of the U.S.S.R. has made it possible considerably to extend the health resorts, not only in the world-famed Caucasian region, which has been greatly enlarged, but also in many other parts of the U.S.S.R., including the Trans-Baikal, Yakutia and the Far East. In the vicinity of Moscow itself mineral waters containing bromine, radium and other valuable therapeutic substances have been found. Geochemistry is flourishing, and discoveries of many valuable minerals are largely the result of geochemical prognoses, which are being made with increasing accuracy and confidence.

The study of marl, alluvium, gravels, sands, clays, etc., is making rapid headway, particularly in connexion with the building of large structures and hydro-technical projects. Data on engineering geology and hydro-geology obtained during the construction of the Palace of Soviets, the Moscow Metro, the White Sea-Baltic Canal, the MoscowVolga Canal, and other projects, have made it possible to plan more confidently large-scale undertakings such as the Volga Dam and the irrigation of the arid steppes of the Trans-Volga region.

The development of life on the earth began with the appearance of primitive plant life and later of animal life. Until recently, geologists have traced the evolution of life more or less systematically from the Cambrian Period. Of Pre-Cambrian formations it was possible to judge only from accidental and isolated discoveries of fossils. But in Siberia fossil remains of Cambrian and PreCambrian age have recently been found in great abundance, and the study of these remains is one of the most fascinating problems of Soviet palæontology. It is possible that ancient Asia may prove to be the cradle of life on the earth, as it was of the higher forms of animal life, mammals, and even of man.

The remains of mammoths have been found in many places, but only in the north of Siberia are complete well-preserved carcasses of these animals, and of their contemporaries, the long-haired rhinoceroses, found in the natural cold storage of frozen swamps. A special expedition has been organized to study these remains in their natural habitat. Remains of the mastodon, an even more ancient member of the elephant family, have been unearthed in the Kuban in North Caucasus. The tusks of this species were spoon-shaped for the purpose of scooping food from silt and muddy water.

The study of fossil animal and plant life in the U.S.S.R. promises to add much that is new to research on the evolution of organisms under various external conditions. 